time when they were putting me through a stringent examination (both written and viva voce) for the extra-licence, as it is only a year and a half since I was admitted. I refrain from making further remarks than to state my own case, as it will show, practically, how the intended changes would affect many hundreds of medical men who are similarly circumstanced. I became a M.R.C.S.L. in 1824, and also a licentiate apothecary. I was five years a resident medical officer of an hospital. In 1832 I went abroad, and in the exercise of my profession I was so fortunate as to realize a moderate independence. I returned to this country in 1845 , solely with an intention of obtaining the degree of doctor of medicine. Residence and university tickets being necessary, I passed the winter sessions of 1845 and 1846 in attending the universities and infirmaries of Edinburgh and Glasgow: the summer of each year was passed in London. In 1846, I was admitted an extra-licentiate of the College of Physicians, and I obtained my doctor's degree last year, having incurred an expense of nearly $£ 800$, solely to attain those distinctions.

Now, the proposed charter has for its object the degrading all graduates in medicine in Great Britain and Ireland, who have taken their degrees subsequently to 1841 , and to reduce them again to a state of pupilage! Nay, more-they are to be punishable if they assume the title of M.D., conferred on them by their respective universities, unless they again submit to an examination such as the newly-to-be-chartered body may think fit to demand; and they must pay a certain sum of money, exclusive of stamps. As well may a charter be granted to the Blue-coat School, to disrate all doctors of laws, M.A. and A.B. of the said universities. Reform, indeed, is wanting; but it is to guard the public and the profession against quacks, and not, as in the present instance, to insure a monopoly of fees. You have my sincere thanks for your long and active exertions in opposing those who would reduce onr profession to a mere trade. I send you my card and address; and I will most willingly come forward with any subscription to aid in opposing such injustice. I will also attend any necessary meeting, and act in any useful way that may be pointed out in that behalf.-I am, Sir, yours,
March, $18 \pm 8$.
A Graduate and Extra-Licentrate.

P.S.-I forward to you, separately, my name and address.

\section{THE PROPOSED NEW CHARTER TO THE COLLEGE OF PHYSICIANS.}

To the Editor of THe Lancet.

Sin, -None of your correspondents have noticed one iniquity of the new Charter of the College of Physicians. There are many graduates of British universities, who, from a variety of motives, have been induced to pass an examination before the elects of the College, and pay their $£ 18$ for their permission to practise as extra-licentiates. I am one of these unfortunates. If the College gets its Charter I can claim to be admitted as a member, because I am a graduate of a British university, of above seven years' standing, but I must pay my $£ 25$, just the same as if I did not belong to the College, had never passed an examination, or paid £18. Is this just? Is it honest?-I am, Sir, your obedient servant,

An Extra-Licentiate.

\section{THE PROJECTED CHARTER TO THE COILEGE OF PHYSICIANS.}

To the Editor of THe LaNCex.

Sir,-I have sent a protest to the College of Physicians against their infamous plan, if true, which I cannot believe, of unlicensing licensed practitioners, and I hope others will do the same. If it becomes the law of the land, I shall either practise in defiance of them, or give up my profession in disgust. I hope you will insert this in your valuable journal.

Cardiff, 1848. I am, Sir, yours obediently,

E. Williams, Extra-Licentiate.

\section{THE LIBELLER OF SURGEONS IN GENERAL PRACTICE. \\ To the Eaitor of The LaNoET.}

Srn,-No man possessing common sense or decency could rise from the perusal of the article in the February number of Fraser's Magazine, entitled "A Plea for Physicians," without a feeling of the deepest disgust and contemptuous pity for the narrow-minded and miserably ignorant writer who could thus slander and belie so numerous, highly respectable, and acknowledgedly useful a body as the surgeons, or, as they are now called, general practitioners, of our country.

Assuming for the nonce that physicians stand in need of a plea, it is a pity that their advocate was not better instructed in the points and requirements of their case. With respect to his estimate of the necessary expense of a professional education, the writer is so very far out that we doubt whether he conld ever have been professionally educated himself. Upon what data the gentleman (?) founds his calculations we.are at a loss to determine; for our experience, and we believe, that of the profession generally, goes to prove that our expenses far exceeded those stated as the maximum of his country gentleman's son physician. We well recollect, in pursuing our hospital studies, numbers of our fellowstudents, whom we met with in Paris and in other countries, who resorted thither for the sole purpose of obtaining an extended knowledge of their profession, who are now general practitioners.

And we would further ask, whether the fifteen hundred or two thousand students to be found annually in London are to be classed with the scion son of the butcher? Write, indeed of forty pound preminms and local schools! -are a tithe of the profession educated in that way? But it were waste of time to follow him further in his unprincipled slander. Such assertions may, indeed, do well to prop up the tottering fabric that is all but falling to crush these high-blown "ornamentals." All of the "lower grade" will view with infinite pleasure the manner in which you have noticed this subject; and we venture to express a hope, in which we are sure all our brethren will join, that you will not let it speedily drop as those of the "higher grade" will not perhaps understand the silence of contempt.

With all due deference to ornamental acquirements, we deprecate the idea of exalting one class of the profession at the expense of another. "Nec sperno, nec timeo."

March 13th, 1848 I am, Sir, your obedient servant, A. Country Practitioner.

\section{THE WAR AGAINST QUACKERY.}

To the Editor of ThE LANCET.

SIR,-It is through the medium of your invaluable journal that I wish to congratulate you on the noble part which you have taken against those most disgusting impostors-quacks. I am of opinion, that if the Apothecaries' Company would make such exertions as you and Sir James Clark have recently done, it would save the public from being made the dupes of those villains, by whom many are sent to an untimely grave, hastened thither in consequence of their folly in believing the lying advertisements by which the columns of our newspapers are so perpetually disgraced.

Now that Sir James Clark has set so noble an example, will not other gentlemen, placed in similar circumstances, do their utmost in endeavouring to root out these impositions to which the suffering public are exposed, and in so doing, enhance the honour of their profession, as well as that of themselves? Hoping the day will soon come when quackery shall be for ever exterminated; that the toleration hitherto shown to it shall be for ever denied it; and that your exertions may be followed by those of the profession generally, and crowned with success, - I remain, Sir, yours most obediently,

Newcastle, 1818. AN Admiren of The Langet.

TESTIMONIAL TO DR. BERNCASTLE.

[COPY OF A LETTER FROM DR. JAMES ARTBUR WLLON TO MR. STEEL, OF LEWISHAM.]

To the Editor of THE LANCET.

LET me thank you, without the delay of a post, for the manly, generous protest which you have entered in THE LANCET of this morning against the cowardly outrage inflicted on Dr. Berncastle by the guardians of the Croydon Poor-law Union and will you be so kind as to let me be one of your " neighbours" on this occasion.

I send a post-office order for $£ 11 s$., as a registration fee, and wish, with all my heart, that, with propriety, I could afford a larger sum, to swell the proposed testimonial. Perhaps, my dear friend, you will receive it from your old teacher in his official capacity as " Senior Physician of St. George's Hospital." I happen, by mere lapse of time, and in conventional phrase, to be among the many so-called 'beads of the profession'' and I should be ashamed, after your appeal, for one day longer to share individually in the discredit that attaches to the chartered bodies 